\title{
Macroeconomic Variables, Government Effectiveness and Sovereign Credit Rating: A Case of Egypt
}

\author{
Osama M. Badr ${ }^{1} \&$ Ahmed F. El-khadrawi ${ }^{2}$ \\ ${ }^{1}$ Faculty of Commerce, Tanta University, Egypt, College of Business, Umm Al-Qura University, KSA. \\ ${ }^{2}$ Faculty of Commerce, Damietta University, Egypt,Faculty of Islamic Economic and Finance, Umm Al-Qura University, \\ KSA. \\ Correspondence: Osama M. Badr, Faculty of Commerce, Tanta University, Egypt, College of Business, Umm Al-Qura \\ University, KSA.
}

Received: March 31, 2016

Accepted: June 8, 2016

Available online: June 21, 2016

doi:10.11114/aef.v3i4.1632

URL: http://dx.doi.org/10.11114/aef.v3i4.1632

\begin{abstract}
Sovereign credit rating reflects the country ability to meet its financial obligations (at present and in future) on its maturities, therefore, it is an important indicator that concerns international financial institutions and foreign investors who are interested in foreign direct investment in order to know the minimum expectation of risks that can be faced in specific country. This paper aims to i) examine the effect of macroeconomic variables on the Egyptian sovereign credit rating (SCR) and ii) also investigate the impact of investment environment (measured by government effectiveness) on the SCR using the dynamic ordinary least squares (DOLS) method over the period from 1990 to 2014. The results indicate that GDP growth, inflation, fiscal balance, reserves, current account balance, public domestic debt, and the government effectiveness have a significant impact on the sovereign credit rating in Egypt. This study has important implications for investors and policymakers.
\end{abstract}

Keywords: sovereign credit rating, GDP growth, inflation, current account balance, public domestic debt and government effectiveness

JEL code: C41, H30, F34, G12, G13, G15

\section{Introduction}

Adopting the concepts of liberalization of foreign trade and financial globalization reflects the role of international financial flows to support economic development efforts by obtaining the necessary funding to stimulate productive activities from external sources by issuing bonds in the international market and FDI. Sovereign Credit Rating (SCR) is one of the most specific indicators to rate the confidence of the international financial institutions and investors, It also determines the interest rate, which government borrows by from such institutions therefore, the possibility of obtaining loans at a competitive cost. In addition, investors have minimum limits of the risks that can be borne by their investments. It is expected that their portfolio consists of bonds, taking into account credit risks that have been identified by credit rating agencies. According to Riasi (2015); Riasi and Amiri (2013), the credit rating can affect the competitiveness of the products of a country in international markets, because credit rating reflects the economic stability of the country and its ability to make the optimal use of funds

In this context, the sovereign credit rating is a determinant for the country ability to get what it needs from the money. In other words, the sovereign credit rating reflects the degree of solvency of the country and its ability to meet its financial obligations (fully and on time) at the present and future..

Further, the flexibility of access to the global capital markets requires obtaining a high degree of credit rating, which is important for emerging economies in general and Egypt in particular, so that when credit rating is weak/low, the cost of necessary borrowing to achieve the required growth rates increases, and the chances of attracting foreign direct investment is reduced.

This study identifies the most important factors that affect the Egyptian sovereign credit rating.

This study is structured as follows. Section II gives an overview of the credit rating agencies in terms of the characteristics of the sovereign rating and the methodology for the classification and determinants of sovereign rating. 
Section III reviews the development of the Egyptian economy and sovereign credit rating during the period under study. Section IV reviews previous studies. Section V presents the model used and the estimation procedures. Section VI discusses the results. Section VII concludes the study.

\section{System of Current Rating and Transformation Rating Process}

Rating categories do not correspond to a particular number, which mean we should transform these categories into numerical values before starting the econometric analysis. We should choice between a linear and non-linear transformation. Choosing a linear transformation, assumes that distance between the rating categories to be identical, while a nonlinear transformation make them different depending on whether the rating categories moves from B to B-. However, it seems that there is no such difference in the results between the two transformation systems; see Ferri et al. (1999), Afonso et al. (2007). Moreover, according to Standard \& Poor's (see Beers and Cavanaugh, 1998) no difference is said to exist between the two types of transformation. In the line with the literature of Cantor and Packer (1996) a linear transformation will be used. Table (1) shows the rating symbols and linear transformation system.

Table (1). Rating symbols for long- term debt "Alignment and linear transformation"

\begin{tabular}{|c|c|c|c|c|c|}
\hline & Moody's & S\&P & Fitch & Interpretation & Numerical \\
\hline \multirow{10}{*}{$\begin{array}{l}\text { Investment-Grade } \\
\text { Ratings }\end{array}$} & Aaa & AAA & AAA & Highest grade & 22 \\
\hline & Aal & $\mathrm{AA}+$ & $\mathrm{AA}+$ & \multirow{3}{*}{ High grade } & 21 \\
\hline & $\mathrm{Aa} 2$ & $\mathrm{AA}$ & $\mathrm{AA}$ & & 20 \\
\hline & Aa3 & AA- & AA- & & 19 \\
\hline & A1 & $\mathrm{A}+$ & $\mathrm{A}+$ & \multirow{3}{*}{ Strong payment capacity } & 18 \\
\hline & $\mathrm{A} 2$ & A & A & & 17 \\
\hline & A3 & A- & A- & & 16 \\
\hline & Baal & $\mathrm{BBB}+$ & $\mathrm{BBB}+$ & \multirow{3}{*}{$\begin{array}{l}\text { Adequate payment } \\
\text { capacity }\end{array}$} & 15 \\
\hline & Baa2 & $\mathrm{BBB}$ & $\mathrm{BBB}$ & & 14 \\
\hline & Baa3 & BBB- & BBB- & & 13 \\
\hline \multirow{12}{*}{$\begin{array}{l}\text { Speculation-Grade } \\
\text { Rating }\end{array}$} & Ba1 & $\mathrm{BB}+$ & $\mathrm{BB}+$ & Speculative & 12 \\
\hline & $\mathrm{Ba} 2$ & BB & BB & "Likely to fulfill & 11 \\
\hline & $\mathrm{Ba} 3$ & BB- & BB- & obligations" & 10 \\
\hline & B1 & $\mathrm{B}+$ & $\mathrm{B}^{+}$ & \multirow{3}{*}{ Highly speculative } & 9 \\
\hline & B2 & B & B & & 8 \\
\hline & B3 & B- & B- & & 7 \\
\hline & Caal & $\mathrm{CCC}+$ & & & 6 \\
\hline & $\mathrm{Caa} 2$ & $\mathrm{CCC}$ & & \multirow{4}{*}{$\begin{array}{l}\text { In default with little } \\
\text { prospects for recovery }\end{array}$} & 5 \\
\hline & Caa3 & $\mathrm{CCC}-$ & $\mathrm{CCC}$ & & 4 \\
\hline & \multirow{2}{*}{$\mathrm{Ca}$} & $\mathrm{CC}$ & & & 3 \\
\hline & & $\mathrm{C}$ & & & 2 \\
\hline & $\mathrm{C}$ & $\mathrm{C}$ & DDD & In default & 1 \\
\hline
\end{tabular}

Source: Moody 's, S\&P and Fitch Rating Agency

\section{Egyptian Economy and Sovereign credit rating}

Figure (1) show, Tracing Egyptian case in the three credit rating indicators (Moody's, S \& P and Fitch), we find almost similar. in spite of their differences during 2011 that they met in 2012 and came back to difference in assessment during 2013 but met again in 2014. We cannot consider this difference hinders assessment uniformity. For this we studied Moody's as a proxy of the three indicators

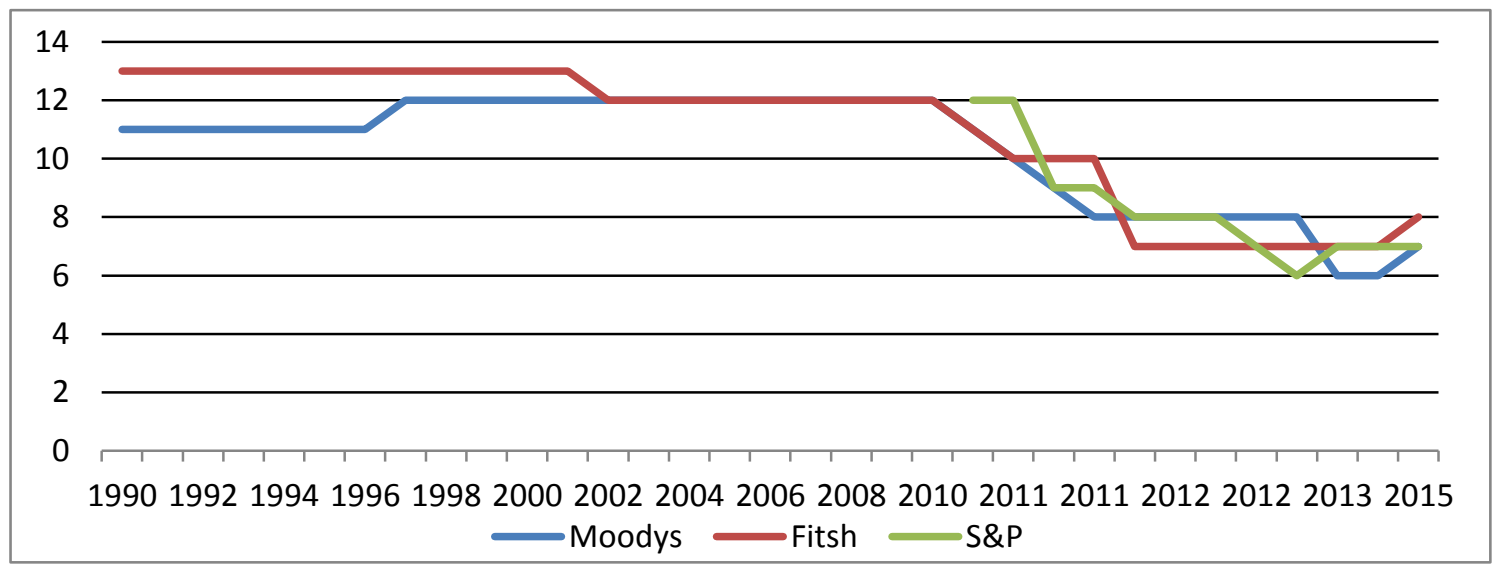

Fig (1). Egypt sovereign credit rating 


\subsection{Determinants of Sovereign Credit Ratings}

To determine the rating criteria, the three agencies (Moody's, S\&P and Fitch) depend on numerous economic, social and political factors. However, it is may be difficult to identify the relationship between these factors and sovereign credit rating, in part because some of these factors are not quantifiable. Even for quantifiable factors, determining the relative weight for each factor is difficult because the two agencies relay on a large number of factors.

\section{Literature Review}

Since the credit rating has become a critical factor in the international capital flow, many economists have studied the nature of the determinants that affect the sovereign credit rating of emerging and developed markets. In this context, the first systematic study on sovereign credit ratings was provided by Cantor and Paker (1996). They examine the determinants of sovereign rating specified by the Moody's and Standard \& Poor's (S\&P), using a sample of 49 countries (developed and emerging countries) using ordinary least square (OLS). They employed eight macroeconomic variables, namely: GDP per capita, GDP growth rate, inflation, fiscal balance as a percentage of GDP, external debt as a percentage of total exports, current account balance as a percentage of GDP, Indicators for each of the economic development and default history. The results show that the previous variables explain $90 \%$ of the changes in both sovereign credit rating and agency rankings. However, GDP per capita only explains $80 \%$ of changes in the sovereign credit rating.

Following Cantor and Paker study (1996), Afonso (2002) examines the impact of previous variables on the sovereign credit rating in 81 developed and developing countries using a linear and logistic transformation. He argues that the variables selected are significant in explaining the credit rating. The study also confirms that external debt has a great effect on developing countries. In a subsequent study, Afonso et al. (2011) examine the factors affecting sovereign rating both in the long and short-term using the three main international rating agencies data, over the period 1995-2005. The results provide evidence that changes in GDP per capita, GDP growth rate, government debt, and government budget have significant impact on the short-run credit rating. However, default history, government effectiveness, external debt and international reserves are the most significant variables in the long run.

Haque et al. (1996) analyze the effect of some economic determinants on country creditworthiness indicators in 60 developing countries covering the period from 1980 to 1993. The findings provide evidence that macroeconomic fundamental variables (e.g. the ratio of foreign reserves to imports, the ratio of the current account balance to GDP, growth rate, and inflation) explain a large amount of volatility in the credit ratings. The study confirms that the credit rating is adversely affected by an increase in international interest rates for all studied countries.

Rowland and Torres (2004) investigate the determinants of both the spread of sovereign bonds and creditworthiness of issuers using panel data model for a sample of 16 emerging countries cover the period from 1987 to 2002. The results suggest that the growth rate, the ratio of debt to GDP, the ratio of international reserves to GDP, and the ratio of debt to exports are significant explanatory variables for the spread as well as of the creditworthiness. Moreover, the spread is also determined by the ratio of debt service payments to GDP, and the ratio of exports to GDP, while inflation and default dummy variable are also important determinants for creditworthiness.

In contrast to the previous results, some studies found that the variables used in the study of Cantor and Paker (1996) are not significant over time, especially when assessment of credit rating during financial crisis of East Asia. For instance, Ferri et al (1999) suggested that short-run debt relative to international reserves is most significant variable apart from variables stipulated in the study of cantor and Paker (1996). They also find that rating adjustments are pro-cyclical rather than counter-cyclical. Similarly, Mora (2005) argued about the role of credit rating agencies in aggravation of the East Asian crisis by excessively downgrading sovereign credit rating for those countries. The findings provide evidence consistent with Ferri (1999) as rating adjustments are pro-cyclical. The results indicated that, predicted ratings were lower than assigned ratings before the period of crisis, mostly matched predicted ratings during the crisis period, and did not increase as much as predicted ratings after the crisis.

Charlotte (2002), explore the determinants of sovereign credit rating for some emerging markets by using solely quantitative explanatory variables. The results support the view of Ferri (1999) that rating changes during the Asia crisis are pro-cyclical. The study attributed the reason for this imbalance to a number of omitted variables, such as the soundness of banking sector, social and political factors which could explain an important aspect of these imbalances.

In addition to the previous studies, many other studies have addressed the determinants of credit rating on single country. For instance, the study of Budina and Mantchev (2000) on Bulgarian economy. They applied a cointegration framework and found a positive impact of reserves and exports on bond price. While this relation was negatively related with both real effective exchange rate and Mexican nominal exchange rate depreciation. 
Rajas and Jaque (2003) explore the determinants of sovereign spread of Chile, the results suggest that sovereign spread significantly affected by debt to reserves ratio, economic activity, and US interest rate.

Arefjevs and Braslinš (2013), investigate the determinants of sovereign ratings of Latvia over the period 1997-2012 obtaining data from the three main rating agencies and using ordinary least square regression. The findings provide evidence that increases in both GDP growth rate and fiscal balance have positive effects on sovereign credit rating while inflation and unemployment have a negative impact on it.

\section{Method}

In our study, we use regression analysis to find the relative significant variables influencing the sovereign credit rating. The variables have been determined as the most macroeconomic variables repeatedly cited in the two agencies rating reports as determinants of sovereign credit rating. More specifically, we estimate the following model:

$$
\begin{aligned}
& \quad S_{t}=a_{0}+a_{1} G D P g_{t}+a_{2} I n f_{t}+a_{3} B D_{t}+a_{4} \operatorname{Res}_{t}+a_{5} E x b_{t} \\
& +a_{6} E x d_{t}+a_{7} R E E R_{t}+\varepsilon_{t}
\end{aligned}
$$

Where (SR ) stands for Moody's sovereign rating grade, (GDPg) is average annual real GDP growth rate, (Inf) is the consumer price inflation rate, (BD) is central government budget deficit relative to GDP, (Res) is the international reserves, (Exb) is the current account balance as a percentage of GDP, (Exd) is the external debt to export ratio, (REER) is the real effective exchange rate.

From equation (1) we expect the regression coefficients of GDP growth rate, and international reserves holds to be positive effects on sovereign rating. While these relationship is expected to be negative with inflation, government budget deficit, and real effective exchange rate. Finally, current account balance has uncertain impact on sovereign credit rating. On the one hand, if the current account deficit reflects an excess of imports over exports, it may be indicative of competitiveness problems, which undermining long-term sustainability. Alternatively, the deficit may reflect rapid accumulation of fixed investment, which should lead to a highly productive, growing economy and improved sustainability over the medium term.

The regression is run on quarterly data obtained from International Financial Statistic (IFS), International Debt Statistic (IDS), and Central Bank of Egypt (CBE). The sovereign credit rating data for Egypt is from Moody's. Finally, the (REER) data is from Bruegel web site. The data covering period from 1990 to 2014.

\subsection{The Estimation Procedures}

For estimating equation (1) we use the dynamic ordinary least squares (DOLS) developed by Stock and Watson (1993). According to Stock and Watson, the DOLS improves on OLS by coping with small sample and dynamic sources of bias. This approach is, in contrast with Johansen method, a robust single equation approach which corrects for regressor endogeneity by the inclusion of lags and leads of first differences of regressors. The number of Lags and leads used to estimate DOLS equation are chosen using Bayesian information criterion (BIC). The DOLS method estimates the long-run coefficients. However, if there is a cointegrating relationship between sovereign credit rating and explanatory variables in the right-hand side in equation (1), then we need to examine the short-run relationship between variables. So, we use OLS to estimate error correction model (ECM), which is given by the following equation:

$$
\begin{gathered}
\Delta \mathrm{S} R_{t}=\omega+\mu \hat{\varepsilon}_{t-1}+\sum_{i=1}^{n} b_{1 i} \Delta G D P_{g_{t-i}}+\sum_{i=1}^{n} b_{2 i} \Delta I n f_{t-i}+ \\
+\sum_{i=1}^{n} b_{3 i} \Delta B D_{t-i}+\sum_{i=1}^{n} b_{4 i} \Delta R e s_{t-i}+\sum_{i=1}^{n} b_{5 i} \Delta E x b_{t-i}+\sum_{i=1}^{n} b_{6 i} \Delta E x d_{t-i}+\sum_{i=1}^{n} b_{7 i} \Delta R E E R_{t-i} \\
++v_{t}
\end{gathered}
$$

In which $\Delta$ is the first difference. $\mu$ is the coefficient of one period lag residual which represents the speed of adjustment to the long-run equilibrium. It should be negative and statistically significant. The number of lags (n) for explanatory variables is chosen using the Schwartz information criteria (SIC).

\subsection{Estimation Results}

Before running the estimation, it is familiar to test whether the variables of equation (1) are stationary or integrated for the same order one (namely I (1)). For this purpose we apply Augmented Dickey-Fuller (ADF) and Phillips Peron (PP) unit root tests. Table (A) in Appendix report the results of tests The results provide evidence that all variables are stationary in their first differences, and therefore they are cointegrated.

It is important to note that equation (1) is first estimated inclusive of all the considerable variables. The results, which not reported her, imply that all the variables are significant and have the expected signs, except for external debt to exports ratio, and real effective exchange rate which were insignificant. In this circumstance, the equation (1) was 
re-estimated after excluding the two variables.

Table 2 reports the results of cointegration equation (1). The elements of the cointegrating vector have signs consistent with what we expected. The coefficients of both GDP growth rate and international reserves have positive and significant impacts on the sovereign rating. The estimates imply that 1 percent increase in GDP growth and reserves may upgrade the sovereign rating by 0.33 percent and 6.89 percent respectively. As also consistent with the predictions, Inflation, and Budget deficit to GDP has negative effect on the long-run score of sovereign rating. The results show sovereign rating elasticities of around 0.09 , and 0.06 , associated with these two determinants respectively. The $\mathrm{R}$-squared is 0.62 implying that 62 per cent of Fluctuations in the sovereign credit rating is explained by explanatory variables used in equation (1).

Table (2). Estimates for sovereign credit rating Equation

\begin{tabular}{|c|c|c|}
\hline \multicolumn{3}{|c|}{ Cointegrating Relation Equation 1: Dependent Variable : $(\mathbf{S R})_{\mathbf{t}}$} \\
\hline & Coefficient & t-Statistic \\
\hline $\mathrm{C}$ & 9.65 & $(12.31)^{*}$ \\
\hline$G D P_{a}$ & 0.331 & $(2.54) * *$ \\
\hline Inf & -0.097 & $(-2.17)^{* * *}$ \\
\hline$B d$ & -0.063 & $(-2.47)^{* *}$ \\
\hline Res & 6.89 & $(2.14)^{* * *}$ \\
\hline$E x b$ & -0.238 & $(3.19)^{*}$ \\
\hline$R^{2}$ & \multicolumn{2}{|c|}{0.62} \\
\hline D.W & \multicolumn{2}{|c|}{1.31} \\
\hline ADF & & \\
\hline Breusch-p & \multicolumn{2}{|c|}{0.590} \\
\hline LM & \multicolumn{2}{|c|}{0.108} \\
\hline Normality & \multicolumn{2}{|c|}{0.197} \\
\hline
\end{tabular}

Table (3). Estimates for sovereign credit rating Equation

\begin{tabular}{|c|c|c|}
\hline \multicolumn{3}{|c|}{ Short-run Dynamic Equation 2: Dependent Variable : $(\mathbf{S R})_{\mathbf{t}}$} \\
\hline & Coefficient & t-Statistic \\
\hline$G D P_{g}$ & 0.051 & $(0.754)$ \\
\hline $\operatorname{Inf}$ & -0.026 & $(-1.12)$ \\
\hline$B d$ & -0.054 & $(-1.77)^{* * *}$ \\
\hline Res & 9.12 & $(4.03)^{*}$ \\
\hline Exb & 0.130 & $(2.11)^{* *}$ \\
\hline$S R_{t-1}$ & 0.584 & $(4.38)^{*}$ \\
\hline$\mu$ & -0.278 & $(-1.89)^{* * *}$ \\
\hline$R^{2}$ & \multicolumn{2}{|r|}{0.76} \\
\hline D.W & \multicolumn{2}{|r|}{2.27} \\
\hline $\mathrm{ADF}$ & \multicolumn{2}{|r|}{$-5.71(<-2.67(1 \%))$} \\
\hline Breusch-p & \multicolumn{2}{|r|}{0.839} \\
\hline LM & \multicolumn{2}{|r|}{0.053} \\
\hline Normality & \multicolumn{2}{|r|}{0.151} \\
\hline
\end{tabular}

Notes: $* * *$, and $* * *$ denote statistical significance at $1 \%, 5 \%$, and $10 \%$ levels, respectively. D.W. is the Durbin-Watson statistic for serial autocorrelation. ADF is the Augmented Dickey-Fuller test for the stationarity of the residuals. Breusch-p. refers to Breusch- pagan test for heteroscedasticity. LM. denotes the Breusch-Godfrey Serial Correlation LM test for the residuals. Normality. Refers to Jarque-Bera Normality test for the residuals.

\section{Robustness of Estimation}

In order to check the robustness and validity of our results, we adding two more variables in our model which are susceptible to influence sovereign credit rating. The add variables are consists of public domestic debt to GDP(PDD), and government effectiveness(Govef). The public debt coefficient is expected to be negative, while we expect a positive relationship between government effectiveness and sovereign rating. As shown in table (A) in appendix, the two variables are stationary in their first differences. Therefore, the variables can be used in their levels beside other basic variables, provides that they are cointegrated. Tables (4) and (5) reports estimation results for equation (1) by adding the new variables one at a time as in column (1) and (2), or together as in column (3). Once again, the real exchange rate, GDP per capita, and external debt to export ratio are excluded from the independent variables list as they turns out 
statistically insignificant. The results provide evidence that the two variables have the predicted signs and both are significant whether in long-run or short-run. The results show that $1 \%$ increase in public domestic debt reduces the sovereign credit rating by 0.08 to 0.13 percentage point in the long-run, while this impact is about 0.066 , in the short-run. The results also indicate that government effectiveness has positive impact on sovereign credit rating. This indicates that Moody's takes qualitative measurement into account. It's important to note that adding new variables did not change the primary results, which provide evidence of the robustness of the estimation results. Finally, the adjustment force is still high and statistically significant (the coefficient range is from 0.66 to 0.81 ).

Table (4). Robustness Test

\begin{tabular}{|c|c|c|c|c|c|c|}
\hline \multicolumn{7}{|c|}{ Cointegrating Relation Equation: Dependent Variable : $(\mathbf{S R})_{\mathrm{t}}$} \\
\hline & \multicolumn{2}{|c|}{$(1)$} & \multicolumn{2}{|c|}{ (2) } & \multicolumn{2}{|c|}{ (3) } \\
\hline & Coefficient & $\mathrm{t}$-Statistic & Coefficient & $\mathrm{t}$-Statistic & Coefficient & t-Statistic \\
\hline $\mathrm{C}$ & 4.35 & $(2.93)^{*}$ & 16.69 & $(11.14)^{*}$ & 11.22 & $(3.39)$ \\
\hline$G D P_{g}$ & 0.111 & $(1.87)^{* * *}$ & 0.138 & $(1.95)^{* *}$ & 0.122 & $(2.01)^{* *}$ \\
\hline Inf & -0.124 & $(-2.77)^{*}$ & -0.079 & $(-2.30)^{* *}$ & -0.118 & $(-3.06)^{*}$ \\
\hline$B d$ & -0.046 & $(-1.86)^{* * *}$ & -0.049 & $(-1.94)^{* *}$ & -0.087 & $(1.79)^{* * *}$ \\
\hline Res & 8.35 & $(2.93)^{*}$ & 1.23 & $(4.36)^{*}$ & 1.16 & $(4.05) *$ \\
\hline$E x b$ & 0.182 & $(3.26)^{*}$ & 0.391 & $(6.60)^{*}$ & 0.341 & $(3.92)^{*}$ \\
\hline$P D D$ & --- & --- & -0.127 & $(-4.66) *$ & -0.082 & $(-2.20) * *$ \\
\hline Govef & 0.127 & $(5.52)^{*}$ & --. & --- & 0.065 & $(1.88) * * *$ \\
\hline$R^{2}$ & \multicolumn{2}{|c|}{0.92} & \multicolumn{2}{|c|}{0.85} & \multicolumn{2}{|c|}{0.95} \\
\hline D.W & \multicolumn{2}{|c|}{2.13} & \multicolumn{2}{|c|}{1.84} & \multicolumn{2}{|c|}{1.89} \\
\hline $\mathrm{ADF}$ & \multicolumn{2}{|c|}{$-4.78(<-3.88(1 \%))$} & \multicolumn{2}{|c|}{$-4.35(<-3.76(1 \%))$} & \multicolumn{2}{|c|}{$-3.81(<-3.06(5 \%))$} \\
\hline Breusch-p & \multicolumn{2}{|c|}{0.970} & \multicolumn{2}{|c|}{0.858} & \multicolumn{2}{|c|}{0.981} \\
\hline LM & \multirow{2}{*}{\multicolumn{2}{|c|}{$\begin{array}{l}0.496 \\
0.448\end{array}$}} & \multicolumn{2}{|c|}{0.068} & \multicolumn{2}{|c|}{0.100} \\
\hline Normality & & & \multicolumn{2}{|c|}{0.608} & \multicolumn{2}{|c|}{0.528} \\
\hline
\end{tabular}

Table (5). Robustness Test

\begin{tabular}{|c|c|c|c|c|c|c|}
\hline & \multicolumn{2}{|c|}{ (1) } & \multicolumn{2}{|c|}{$(2)$} & \multicolumn{2}{|c|}{ (3) } \\
\hline & Coefficient & t-Statistic & Coefficient & t-Statistic & Coefficient & t-Statistic \\
\hline$G D P_{g}$ & 0.081 & $(1.32)$ & 0.035 & $(0.606)$ & 0.060 & $(1.02)$ \\
\hline $\operatorname{Inf}$ & -0.072 & $(-2.82)^{* *}$ & -0.059 & $(-2.55)^{* *}$ & -0.067 & $(-2.91)^{*}$ \\
\hline$B d$ & -0.038 & $(-1.78)^{* * *}$ & -0.075 & $(-1.77)^{* * *}$ & -0.060 & $(-1.80) * * *$ \\
\hline Res & 9.20 & $(4.42)^{*}$ & 1.23 & $(6.64)^{*}$ & 1.10 & $(5.44)^{*}$ \\
\hline$E x b$ & 0.202 & $(3.02)^{*}$ & 0.268 & $(3.89)^{*}$ & 0.247 & $(3.64)^{*}$ \\
\hline$P D D$ & --- & --- & -0.067 & $(-3.11)^{*}$ & -0.065 & $(-3.15)^{*}$ \\
\hline Govef & 0.050 & $(2.21) * *$ & --- & --- & 0.027 & $(1.85)^{* * *}$ \\
\hline$S R_{t-1}$ & 0.369 & $(2.73)^{*}$ & 0.360 & $(3.03)^{*}$ & 0.263 & $(1.95)^{* * *}$ \\
\hline$\mu$ & -0.812 & $(-3.09) *$ & -0.665 & $(-2.44) * *$ & -0.689 & $(-2.62) * *$ \\
\hline$R^{2}$ & \multicolumn{2}{|c|}{0.90} & \multicolumn{2}{|c|}{0.90} & \multicolumn{2}{|c|}{0.92} \\
\hline D.W & \multicolumn{2}{|c|}{1.87} & \multicolumn{2}{|c|}{2.02} & \multicolumn{2}{|c|}{1.87} \\
\hline $\mathrm{ADF}$ & \multicolumn{2}{|c|}{$-4.04(<-3.92(1 \%))$} & \multicolumn{2}{|c|}{$-5.64(<-3.92(1 \%))$} & \multicolumn{2}{|c|}{$-4.451(<-3.92(1 \%))$} \\
\hline Breusch-p & \multicolumn{2}{|c|}{0.890} & \multicolumn{2}{|c|}{0.971} & \multicolumn{2}{|c|}{0.994} \\
\hline LM & \multicolumn{2}{|c|}{0.082} & \multicolumn{2}{|c|}{0.110} & \multicolumn{2}{|c|}{0.094} \\
\hline Normality & \multicolumn{2}{|c|}{0.328} & \multicolumn{2}{|c|}{0.608} & \multicolumn{2}{|c|}{0.940} \\
\hline
\end{tabular}

\section{Conclusion}

This paper aims to investigate the determinants of Egypt's sovereign credit rating assigned by Moody's agency. The importance of studying the sovereign credit rating in Egypt is being one of important factors that help government to borrow from foreign countries and international financial institutions at competitive cost as well as it facilitates attracting FDI which requires obtaining a high credit rating. There are many factors affecting the credit rating. This paper finds that there are six factors that play the most important role affecting the sovereign credit rating in Egyptian case. These factors are: GDP growth, inflation, fiscal balance, reserves, current account balance, and public domestic debt. In addition, the study finds that the government effectiveness indicator is a significantly determinant for the country rating. This shows that sovereign credit rating classification process depends on both quantitative and qualitative variables. Thus, the study concludes the following.

1. The Egyptian economy suffers from a severe inflation and decline in local currency value against foreign 
currencies. This inflation is a kind of stagflation

2. It seems that current account deficit plays critical roles in determining the rating rank, which reflects structural weaknesses and increases risk of external influences. This deficit is due to the large deficit in trade structure where We experience a decrease in export due to increase foreign component cost in domestic product as an outcome of local currency's value depreciation against foreign currencies, which leading to raise domestic product prices, putting it outside local and international market competition, thus lead to domestic market recession and an increase in import due to weaknesses in production structure and inability of local products on price competition with foreign products. In the same time, Egypt suffers from a decrease in the services surplus and a sharp drop in net transport revenues due to political and social unrest in recent years.

3. Increasing public spending in luxury matters reduces the society benefits from this tunnel and does not help increase investment, plus spending the International reserves in consumable maters, which do not lead to economic returns, thus increases the budget deficit with more negative impact on the credit rating .

4. Conflicts of policies and decisions give negative impacts on the credit rating.

The results of this have important implications for policymakers to increase the sovereign credit rating of Egypt:

First, government should reduce hyperinflation but the central bank must take into consideration the domestic market recession when start fighting inflation by raising borrowing costs and reduces commercial banks' ability to create credit .

Second, government should reduce current account deficit and increase international reserves position,

Third, government must use measures to reduce the fiscal deficit by rationalizing public spending, without prejudicing to capital spending allocation, putting into consideration the negative effects of the government spending reduction, at least in the short term .

Fourth, government should have a good coordination between policies and decisions especially fiscal and monetary policies Also, it is important to adopt supportive economic policies for investment and economic growth away from distortionary measures, and it should use supply side economics efficiently and effectively

Table A: Unit Root Tests

\begin{tabular}{|c|c|c|c|c|}
\hline & \multicolumn{2}{|c|}{ ADF } & \multicolumn{2}{|c|}{ PP } \\
\hline Variables & Level & $\begin{array}{c}\text { First } \\
\text { Difference }\end{array}$ & Level & $\begin{array}{c}\text { First } \\
\text { Difference }\end{array}$ \\
\hline$G D P_{p c}$ & $\begin{array}{l}-4.78 * \\
(-3.76)\end{array}$ & $\begin{array}{c}-2.67 * * * \\
(-2.64)\end{array}$ & $\begin{array}{c}-2.05 \\
(---)\end{array}$ & $\begin{array}{c}-2.60 * * \\
(-1.95)\end{array}$ \\
\hline$G D P_{g}$ & $\begin{array}{l}-3.86^{*} \\
(-3.76)\end{array}$ & $\begin{array}{c}--3.69 * * \\
(-3.67)\end{array}$ & $\begin{array}{c}-3.37 * * \\
(-2.99)\end{array}$ & $\begin{array}{l}-7.78^{*} \\
(-3.75)\end{array}$ \\
\hline Inf & $\begin{array}{c}-2.58 \\
(---)\end{array}$ & $\begin{array}{l}-6.81^{*} \\
(-3.75)\end{array}$ & $\begin{array}{c}-2.48 \\
(---)\end{array}$ & $\begin{array}{l}-6.78^{*} \\
(-3.75)\end{array}$ \\
\hline$B D$ & $\begin{array}{l}-2.45 \\
(---)\end{array}$ & $\begin{array}{l}-7.36^{*} \\
(-3.76)\end{array}$ & $\begin{array}{c}-2.69 * * * \\
(-2.63)\end{array}$ & $\begin{array}{l}-7.77 * \\
(-3.76)\end{array}$ \\
\hline Res & $\begin{array}{c}-2.01 \\
(---)\end{array}$ & $\begin{array}{l}-4.45^{*} \\
(-3.85)\end{array}$ & $\begin{array}{c}-2.16 \\
(---)\end{array}$ & $\begin{array}{l}-3.58^{*} \\
(-3.75)\end{array}$ \\
\hline$E x b$ & $\begin{array}{c}-1.62 \\
(--)\end{array}$ & $\begin{array}{l}-3.94 * \\
(-3.76)\end{array}$ & $\begin{array}{c}-1.62 \\
(---)\end{array}$ & $\begin{array}{l}-3.97 * \\
(-3.76)\end{array}$ \\
\hline Exd & $\begin{array}{c}-2.10 \\
(---)\end{array}$ & $\begin{array}{l}-4.72 \\
(-3.75)\end{array}$ & $\begin{array}{l}-3.08^{* *} \\
(-2.99)\end{array}$ & $\begin{array}{l}-4.85^{*} \\
(-3.75)\end{array}$ \\
\hline$R E E R$ & $\begin{array}{c}-2.21 \\
(---)\end{array}$ & $\begin{array}{l}-6.19^{*} \\
(-3.75)\end{array}$ & $\begin{array}{c}-2.66 * * * \\
(-2.63)\end{array}$ & $\begin{array}{l}-5.67^{*} \\
(-3.75)\end{array}$ \\
\hline$P D D$ & $\begin{array}{c}-0.77 \\
(---)\end{array}$ & $\begin{array}{l}-3.39 * * \\
(-3.00)^{*}\end{array}$ & $\begin{array}{c}-1.24 \\
(---)\end{array}$ & $\begin{array}{c}-3.35^{* *} \\
(-3.00)\end{array}$ \\
\hline$G E$ & $\begin{array}{c}-.007 \\
(---)\end{array}$ & $\begin{array}{c}-3.14 * * \\
(3.05)\end{array}$ & $\begin{array}{c}-0.12 \\
(--)\end{array}$ & $\begin{array}{c}-3.02 * * * \\
(-2.66)\end{array}$ \\
\hline
\end{tabular}

Notes: $*, * *$, and $* * *$ denote statistical significance at $1 \%, 5 \%$, and $10 \%$ levels, respectively

(---), not significant variable at the confidence levels of $1 \%, 5 \%$ or $10 \%$ 


\section{References}

Afonso, A. (2002). "Understanding the determinants of government debt ratings: Evidence for the two leading agencies”. Working Paper No. 2002/02. Lisbon: Universitade Tecnica de Lisboa.

Afonso, A., Gomes, P., \& Rother, P. (2011). "Short - and long - run determinants of sovereign debt credit ratings". International Journal of Finance \& Economics, 16(1), 1-15

Arefjevs, I., \& Braslinšs, Ģ. (2013). "Determinants of Sovereign Credit Ratings - Example of Latvia”. New Challenges of Economic and Business Development. University of Latvia.

Beers, D. T., \& Cavanaugh, M. (1998). “Sovereign Credit Ratings: A primer”. Standard \& Poor's.

Budina, N., \& Mantchev, T. (2000). "Determinants of Bulgarian Brady bond prices: An empirical assessment". Retrieved November 29, 2005 from The World Bank database.

Cantor, R., \& Packer, F. (1996). "Determinants and impact of sovereign credit rating”. Federal Reserve Bank of New York Economic Policy Review, (October), 1-15.

Charlotte, A. (2002). "Sovereign credit ratings". Deutsch Bank Research, Quantitative Analysis, Notes in Economics \& Statistics, No. 02-1.

Ferri, G., Liu, L.-G., \& Stiglitz, J. E. (1999). "The procyclical role of rating agencies: Evidence from the East Asian crisis". Economic Notes, 28(3), 335-355.

Haque, N., Kumar, M., Mathieson, D., \& Mark, N., (1996). "The Economic Content of Indicators of Developing Country Creditworthiness". IMF, Staff Papers, 43(4).

Mora, N. (2005). “Sovereign credit ratings: Guilty beyond reasonable doubt?”. Working paper, MIT. https://www.aub.edu.lb/fas/ife/Documents/downloads/series1_2005.pdf

Riasi, A. (2015). "Competitive Advantage of Shadow Banking Industry: An Analysis Using Porter Diamond Model" Business Management and Strategy, 6(2), 15-27. http://dx.doi.org/10.5296/bms.v6i2.8334

Riasi, A., \& AmiriAghdaie, S. F. (2013). "Effects of a Hypothetical Iranian Accession to the World Trade Organization on Iran's Flower Industry". Consilience: The Journal of Sustainable Development, 10(1), 99-110. http://dx.doi.org/10.7916/D8HQ3ZK8

Rojas, A., \& Jaque, F. (2003). “Determinants of the Chilean sovereign spread: Is it purely fundamentals?”. Chile: Banco Central de Chile.

Rowland, P., \& José, L. T. (2004). "Determinants of Spread and Creditworthiness for Emerging Market Sovereign Debt: A Panel Data Study", Borradores de Economía, Banco de la República, Bogotá.

\section{$(\mathrm{cc}) \mathrm{BY}$}

This work is licensed under a Creative Commons Attribution 3.0 License. 